\author{
Andrzej Kondej \\ University of Bialystok \\ Faculty of Economics and Management \\ Department of Basis and Strategies Management \\ e-mail: andrzej.kondej@uwb.edu.pl
}

\title{
Transformacja handlu detalicznego Fast Moving Consumer Goods (FMCG) w Polsce po 1989 roku
}

\section{Transformation of the retail trade of FMCG in Poland after 1989}

The aim of the article is to present and analyze the deep transformations that have occurred in the retail trade of the FMCG in Poland after 1989. It presents the phase nature of the transformations of this market, which led to its current diversified structure. Both the development of domestic trade and the expansion of foreign trade corporations were taken into account. The content includes issues such as market diversification and concentration, development within particular formats and the phenomenon of convergence.

The paper takes advantage of ongoing qualitative and quantitative research (since 2012) of the FMCG retail market in Poland by Kondej Marketing. The survey is based on aggregation and analysis of available secondary data, market observations and primary direct interviews.

Particular emphasis is placed on the impact of the demand factor on the development and shaping of the structure of this market. The influence of disposable income on the situation within the retail market of the FMCG industry was comprehensively presented. The preferences and purchasing behavior of Polish consumers, which are unique on a European scale, were also taken into account. This applies, in particular, to the attitude of smart shopping and the tendency to buy in stores located near buyers' place of residence. The article presents the thesis that the purchasing preferences of Polish consumers have a significant impact on the development of the sector and its structure 
Keywords: retail trade, FMCG, transformation, trade formats, structure of trade

JEL Classification: D12, D40, N84

\section{Wprowadzenie}

W ciągu ostatnich 30 lat w Polsce dokonały się głębokie przeobrażenia w handlu detalicznym branży FMCG ${ }^{1}$. Doprowadziły one do obecnej, zdywersyfikowanej i unikatowej w skali europejskiej struktury rynkowej. Można przyjąć założenie, że na ukształtowanie się obecnej struktury rynku wpływ wywierało szereg czynników, zarówno natury podażowej, jak i popytowej. Po stronie uczestników rynku wyszczególnić można handel krajowy, którego inicjatywa została wyzwolona w okresie transformacji społeczno-gospodarczej od 1989 roku. Przyniosło to efekt $\mathrm{w}$ postaci powstania ponad 140 tysięcy placówek handlowych w branży spożywczej, co w skali europejskiej było liczbą niespotykanie wysoką. Polski rynek stał się też miejscem intensywnej ekspansji zagranicznych korporacji handlowych, które zdominowały formaty hipermarketów, dyskontów i sklepów convenience.

Konfrontacja rynkowa handlu krajowego z zagranicznym przyczynić się musiała do stworzenia struktury rynku niemającej odniesienia do innych krajów europejskich. W Polsce funkcjonują i konkurują z sobą sklepy zaliczane do różnych formatów, a konsumenci mają możliwość szerokiego wyboru miejsca dokonywania zakupów. W naszym kraju nie doszło przy tym do wyraźnego zdominowania rynku przez placówki tzw. handlu nowoczesnego (hipermarkety, dyskonty i supermarkety), co jest zjawiskiem charakterystycznym dla takich państw, jak: Francja, Wielka Brytania czy Niemcy.

Głównym celem tego opracowania jest przedstawienie charakterystyki przemian strukturalnych handlu detalicznego FMCG na polskim rynku. Podjęta zostaje próba identyfikacji czynników, które w sposób kluczowy wywierają wpływ na kształtowanie się unikatowej w skali europejskiej struktury polskiego rynku detalicznego branży FMCG. W sposób szczególny uwzględniono wpływ czynnika popytowego, jakim są preferencje i zachowania nabywcze polskich konsumentów, które są unikatowe w skali europejskiej.

\footnotetext{
${ }^{1}$ FMCG (Fast Moving Consumer Goods) - produkty szybko zbywalne.
} 


\section{Rozwój handlu detalicznego FMCG w latach 1989-2017}

\section{Etap I - lata 1989-2005}

W gospodarce centralnie sterowanej handel detaliczny w Polsce do 1989 roku był zdominowany przez sklepy stanowiące własność państwową i spółdzielczą. Placówki handlowe prezentowały niski poziom pod względem wystroju i wyposażenia technicznego, jakości obsługi klientów i asortymentu. Sektor handlowy charakteryzował się strukturalnymi brakami w zakresie zaopatrzenia, był niedoinwestowany i niedostosowany do oczekiwań konsumentów. W porównaniu z liczbą sklepów spółdzielczych i państwowych, stosunkowo mały udział w rynku posiadały małe placówki handlowe należące do prywatnych właścicieli. Ponadto ich funkcjonowanie było ograniczane restrykcyjnymi przepisami i trudnościami w zakresie dostaw towarowych.

Po 1989 roku nastąpiło uwolnienie cen detalicznych spod kontroli państwa, a przepisy dotyczące prowadzenia działalności handlowej zostały wyraźnie zliberalizowane. Wprowadzenie zasad wolnego rynku spowodowało gwałtowne wyzwolenie inicjatywy gospodarczej Polaków, co w kolejnych latach przejawiało się w rozwoju handlu typu bazarowego i uruchamianiu tysięcy straganów i małych sklepów różnych branż ${ }^{2}$.

Zwiększający się popyt i rosnące aspiracje nabywcze konsumentów stworzyły sprzyjający grunt dla stopniowej ekspansji zagranicznych sieci handlowych (Kowalska, 2012, s. 74). Pierwszy zagraniczny hipermarket pojawił się w Polsce w 1995 roku, co stało się początkiem ekspansji sklepów wielkopowierzchniowych w kolejnych latach XX i XXI wieku. Do 2005 roku można było zaobserwować rozwój rynku we wszystkich formatach, co dotyczyło zarówno sklepów należących do kapitału krajowego, jak i zagranicznego. Na początku pierwszej dekady XXI wieku dynamika wzrostu liczby sklepów spożywczych wyraźnie osłabła, co wskazywało na pojawiające się symptomy nasycenia rynku pod względem liczby placówek handlowych.

\section{Etap II - lata 2006-2010}

W 2006 roku po raz pierwszy zanotowano spadek liczby sklepów spożywczych działających na polskim rynku. W latach 2006-2010 regres wahał się od $-0,8 \%$ do $-4,6 \%$ w układzie rocznym (Wykres 1 ). Zjawisko to było szczególnie dostrzegalne w odniesieniu do małych i średnich sklepów mających do $100 \mathrm{~m}^{2}$ powierzchni sprzedażowej, należących w większości do kapitału krajowego.

\footnotetext{
${ }^{2}$ Głównie chodzi o przekształcenie ogólnopolskiej sieci PSS „Społem” i jej podział na samodzielne spółdzielnie działające w skali lokalnej.
} 


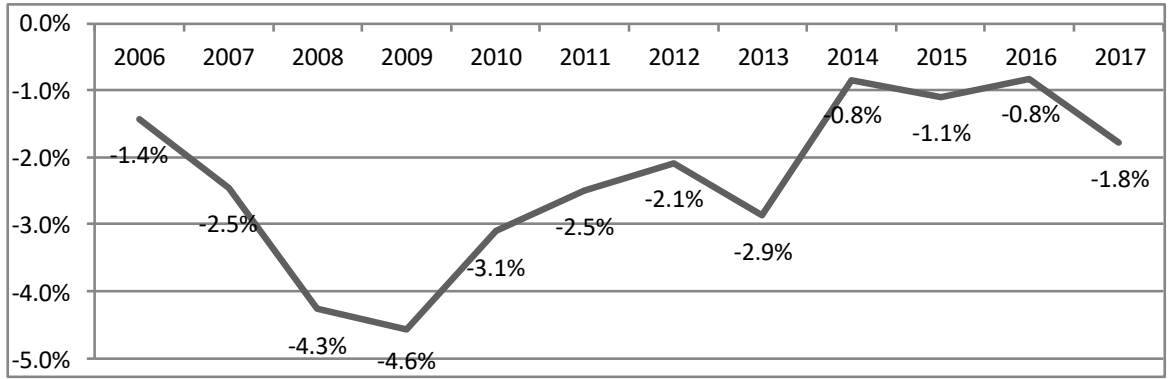

Wykres 1. Regres liczebności sklepów spożywczych w latach 2005-2017

Źródło: Opracowanie własne na podstawie: Baza sieci detalicznych, 2018.

Głównym powodem likwidacji większości małych i średnich sklepów była utrata ich zdolności konkurencyjnych pod względem cenowym, asortymentowym i wizualnym w stosunku do dynamicznie rozwijającego się sektora handlu wielkoformatowego. W najtrudniejszym położeniu znalazły się małe sklepy spożywcze (do $50 \mathrm{~m}^{2}$ powierzchni) zlokalizowane $\mathrm{w}$ zasięgu bezpośredniego oddziaływania nowo powstających dyskontów, supermarketów i hipermarketów (Kosińska-Gębska, Tul-Krzyszczuk \& Gębski, 2011, s. 53). Polscy konsumenci coraz częściej preferowali bowiem duże placówki zagranicznego pochodzenia, które oferowały atrakcyjne produkty w konkurencyjnych cenach, a jednocześnie prezentowały wyższy poziom pod względem wizualizacyjnym i szeroko pojętej jakości obsługi klientów (Dąbrowska \& Słaby, 2011, s. 35).

\section{Etap III - lata 2011-2017}

Konkurencja na rynku detalicznym FMCG intensyfikowała się od początku drugiej dekady XXI wieku. Było to głównie efektem dynamicznego rozwoju sieci dyskontowych, sklepów convenience i supermarketów typu proximity. Odbywało się to kosztem małych i średnich sklepów spożywczych oraz sieci hipermarketów, które stopniowo traciły atuty konkurencyjne na zmieniającym się rynku. W latach 2014-2017 nastąpiło spowolnienie rozwoju dyskontów i sklepów convenience. W tym okresie zaczęła się poprawiać konkurencyjność części sklepów małoformatowych, które przyłączone zostały do dynamicznie rozwijających się sieci handlowych, zorganizowanych głównie w formie franczyzowej i partnerskiej. Pojawiło się zjawisko konkurowania podmiotów handlowych w ramach określonych formatów (np. dyskontów), jak również nasiliła się ogólna rywalizacja na rynku (Sieci detaliczne..., 2016). Efektem tych przeobrażeń jest zdywersyfikowana struktura polskiego rynku, z dużym - jak na warunki europejskie - udziałem handlu małoformatowego.

$\mathrm{Z}$ drugiej strony, cyklicznie wzrasta poziom koncentracji polskiego rynku, będący efektem silnych działań konsolidacyjnych (Kucharska \& Twardzik, 2007, s. 79). Proces ten ma miejsce głównie w formatach małych, średnich i dużych sklepów spożywczych oraz supermarketów, czyli tam, gdzie występuje jeszcze 
duże rozdrobnienie rynku. W warunkach spowolnienia wzrostu liczby sklepów wielkopowierzchniowych większość operatorów skupia się na modernizacji swoich placówek handlowych i dostosowaniu ich do zmieniających się i rosnących oczekiwań nabywców. Jednym z najbardziej wyrazistych przejawów przemian o charakterze jakościowym jest zanikanie wyrazistych wcześniej różnic między formatami i stosowanie przez operatorów nowatorskich rozwiązań handlowych. Zjawisko konwergencji jest zauważalne we wszystkich formatach i prowadzi do pojawiania się takich konceptów, jak m.in. hipermarkety kompaktowe, supermarkety proximity czy dyskonty z cechami supermarketów.

Jako główny czynnik rozwoju polskiego rynku handlu detalicznego FMCG i jego przemian strukturalnym można przyjąć ekspansję sieci handlowych zarządzanych przez korporacje należące do kapitału zagranicznego. Od momentu ich pojawienia się w Polsce w 1995 roku, w ciągu kolejnych 10 lat udział wartościowy sieci wielkoformatowych sukcesywnie się zwiększał i w 2005 roku osiągnął poziom 26\%. Do końca 2017 roku wskaźnik ten wzrósł do poziomu 52,7\%, co wynikało przede wszystkim z silnej ekspansji na polskim rynku sieci dyskontowych (Wykres 2).

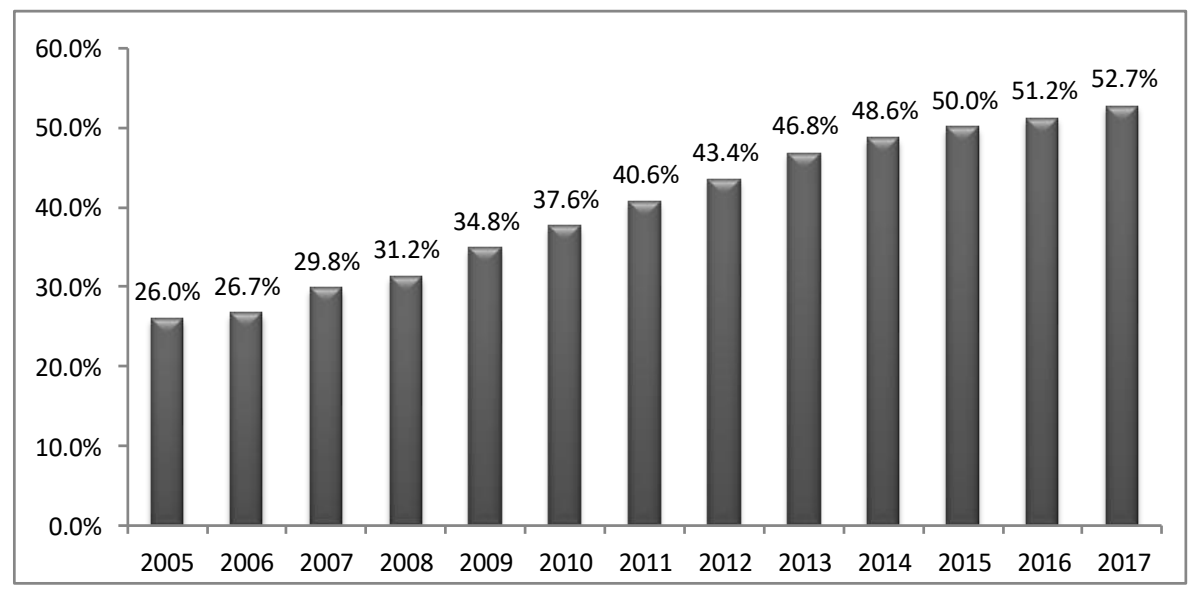

Wykres 2. Udział wartościowy sklepów wielkopowierzchniowych w rynku spożywczym w latach 2005-2017 (w \%)

Źródło: Opracowanie własne na podstawie: Baza sieci detalicznych, 2018.

Ekspansja zagranicznych korporacji handlowych w Polsce miała zróżnicowane podłoże. Kluczową rolę odgrywało dążenie do zwiększania efektu skali oraz przeniesienie konkurencyjności z rynków krajowych na poziom globalny ${ }^{3}$. W tych uwarunkowaniach rozwój działalności w Polsce wynikał z pozytywnej oceny tego ${ }^{3}$ Poziom konkurencyjności przedsiębiorstwa handlowego w decydującym stopniu zależy od skali
działania. 
rynku pod względem jego atrakcyjności w kontekście prowadzenia działalności handlowej. Do sprzyjających czynników rynkowych można zaliczyć:

(1) nieodwracalny proces tworzenia gospodarki wolnorynkowej,

(2) bliskość polskiego rynku w sensie geograficznym ${ }^{4}$,

(3) wzrost gospodarczy i stabilizację ekonomiczną,

(4) stosunkowo dużą liczbę potencjalnych klientów,

(5) stały wzrost indywidualnych dochodów i siły nabywczej mieszkańców,

(6) intensywny wzrost konsumpcyjnych oczekiwań i wymagań nabywców,

(7) deficyt nowoczesnych powierzchni handlowych,

(8) niską konkurencyjność krajowych przedsiębiorstw handlowych (Kaczmarek, 2010, s. 147).

Na szczególne podkreślenie zasługują takie czynniki, jak bliskość geograficzna polskiego rynku i niski poziom konkurencyjności rodzimego handlu. Umożliwiło to szybką ekspansję, gdyż w zdecydowanej większości przypadków rodzimi przedsiębiorcy handlowi nie byli w stanie skutecznie konkurować z działającymi w nieporównywalnie większej skali korporacjami zagranicznymi (Alexander \& Doherty, 2009, s. 122).

\section{Popytowe czynniki rozwoju handlu detalicznego w branży FMCG}

Na rozwój i strukturę handlu detalicznego FMCG w Polsce istotny i coraz silniejszy wpływ wywierają czynniki popytowe. Dotyczy to głównie uwarunkowań demograficznych, poziomu i dynamiki dochodów rozporządzalnych oraz pozafinansowych zachowań nabywczych konsumentów. Na zdywersyfikowanym rynku nabywcy mogą dokonywać swobodnych wyborów odnośnie do miejsca dokonywania zakupów. Z kolei zróżnicowana charakterystyka polskich konsumentów powoduje, że ich decyzje nabywcze sprzyjają funkcjonowaniu różnych form handlu detalicznego (Handel w Polsce..., 2016).

Czynnikiem szczególnie silnie oddziałującym na działalność handlową jest gęstość zaludnienia, gdyż implikuje to liczbę potencjalnych klientów określonych placówek. Na strukturę handlu w Polsce znaczący wpływ wywiera zatem fakt, że około $70 \%$ konsumentów mieszka w miejscowościach liczących poniżej 10 tysięcy mieszkańców i na terenach wiejskich (Analiza PIH..., 2016). Obszary te są mniej atrakcyjne dla operatorów sieci wielkopowierzchniowych, co sprzyja utrzymaniu dużego udziału handlu małoformatowego.

Ważnym czynnikiem popytowym jest również klasa (wielkość) miejscowości. Niezależnie od liczby mieszkańców zachodzi zjawisko proporcjonalnej relacji między wielkością miejscowości a wysokością dochodu rozporządzalnego mieszkańców. W konsekwencji w głównych aglomeracjach jest nie tylko największa liczba potencjalnych klientów, ale również najwyższy poziom dochodów rozpo-

\footnotetext{
${ }^{4}$ Większość korporacji handlowych wywodzi się z krajów Europy Zachodniej.
} 
rządzalnych. Implikuje to największe zainteresowanie tymi lokalizacjami ze strony operatorów sieci wielkoformatowych i sklepów convenience (Wilk, 2013).

Wzrost wartości rynku handlu spożywczego w okresie 2005-2017 w znacznym stopniu opierał się na rosnącym dochodzie rozporządzalnym, który umożliwiał zwiększenie konsumpcji indywidualnej (Grocery retail..., 2016). W tym czasie realny dochód rozporządzalny zwiększył się o $110 \%$, co oznacza średnioroczny wzrost o $6,4 \%$. W odniesieniu do handlu detalicznego w branży spożywczej można dostrzec silną korelację zmiennych charakteryzujących rozwój tego sektora ze wzrostem dochodów rozporządzalnych. Dotyczy to w szczególności silnej współzależności między dochodem rozporządzalnym a takimi parametrami, jak: łączna powierzchnia sprzedażowa sklepów, średnia powierzchnia sprzedaży i sprzedaż na metr kwadratowy.

Wpływ dochodu indywidualnego na sektor handlu detalicznego staje się bardziej czytelny przy uwzględnieniu innych czynników, w tym głównie gęstości zaludnienia (Kondej, 2017, s. 180). W efekcie pojawia się parametr wartości siły nabywczej na jednostkę powierzchni, który posiada kluczowy wpływ na lokalizację placówek handlowych. Dla operatorów rynkowych stanowi to główne kryterium atrakcyjności określonego rynku, gdyż jest pochodną liczby potencjalnych klientów i ich możliwości nabywczych. Na tej podstawie można uzasadnić zjawiska zróżnicowania liczby placówek handlowych w poszczególnych województwach i odmiennej struktury handlu w branży FMCH w układzie przestrzennym. W województwach o wysokiej gęstości zaludnienia i ponadprzeciętnych dochodach indywidualnych istnieje największa liczba sklepów przypadających na jednostkę powierzchni. W regionach tych wyższy jest również udział sklepów wielkoformatowych w ogólnej liczbie sklepów spożywczych. Z kolei obszary o niskiej sile nabywczej charakteryzują się wyższym wskaźnikiem udziału małych i średnich sklepów spożywczych w ogólnej strukturze ilościowej. Zjawisko to wynika bezpośrednio z niższej intensywności konkurencji rynkowej, która jest większa w regionach o wyższym potencjale nabywczym na jednostkę powierzchni.

Analizę wpływu dochodu rozporządzalnego na sytuację w handlu spożywczym w pełniejszy sposób można przeprowadzić na podstawie wydatków na żywność i napoje bezalkoholowe. W okresie 2005-2017 wydatki na tego rodzaju produkty (w cenach stałych z 2005 roku) zwiększyły się o 48\%, co przekłada się na średnioroczny postęp o 3,3\%. Oznacza to znacznie mniejszy wzrost niż analogiczny wskaźnik dotyczący wzrostu dochodu rozporządzalnego. Wynika to ze zjawiska zmniejszenia udziału tego typu wydatków w dochodach rozporządzalnych z 25,5\% w 2005 roku do 17,9\% w roku $2017^{6}$. Potwierdza to proces zmieniającej się struktury konsumpcji i przeznaczania przez konsumentów coraz większej części dostępnych środków finansowych na wydatki wyższego rzędu, niezwiązane z zakupem produktów pierwszej potrzeby.

\footnotetext{
${ }^{5}$ Mierzone w formie CAGR (Compound Annual Growth Rate), oznaczającym skumulowany roczny wskaźnik wzrostu.

${ }^{6}$ Wyliczenie własne na podstawie: Bank Danych Lokalnych.
} 


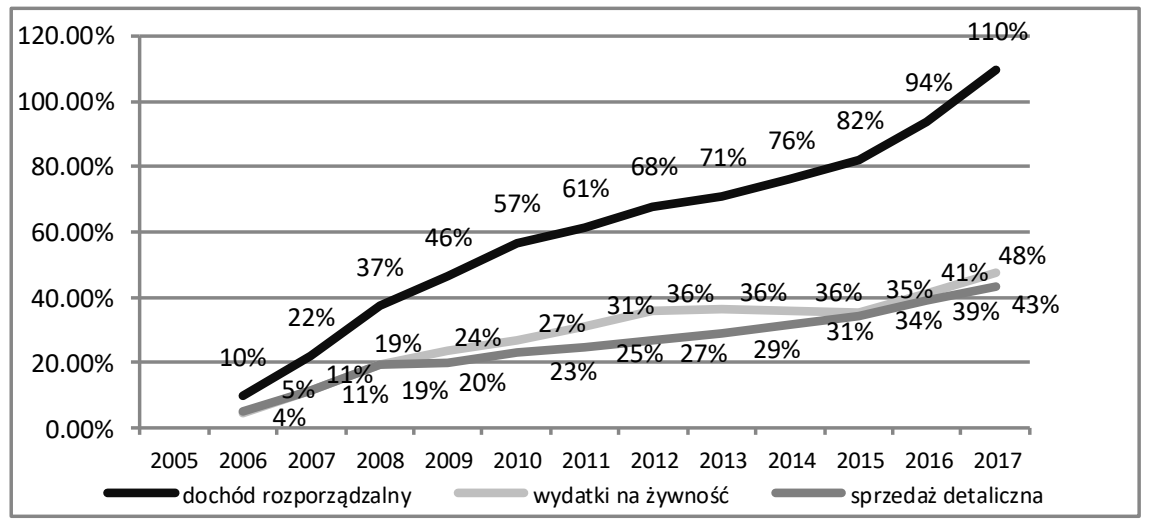

Wykres 3. Dynamika dochodów rozporządzanych, wydatków na żywność i sprzedaży detalicznej sklepów spożywczych w latach 2006-2017 (w cenach 2005 r.)

Źródło: Opracowanie własne na podstawie: Bank Danych Lokalnych, 2018 i Baza Sieci Detalicznych, 2018

Przy stabilnej liczbie ludności Polski ograniczony wzrost wydatków na żywność tworzy barierę rozwoju rynku spożywczego. W efekcie spowalnia to ekspansję największych sieci handlowych, a jednocześnie przyczynia się do ustawicznego spadku liczby małych i średnich sklepów spożywczych. Ograniczony potencjał popytowy na rynku wzmaga konkurencję między operatorami różnych formatów, co przejawia się głównie w agresywnej rywalizacji cenowej i promocyjnej. Bariera popytu skłania właścicieli sieci handlowych do podejmowania zdecydowanych działań rynkowych, takich jak: fuzje, przejęcia i likwidacje trwale nierentownych placówek handlowych. W konsekwencji najsłabsi pod względem ekonomicznym operatorzy tracą zdolności konkurencyjne i zmuszeni są do wycofania się z rynku.

\section{Preferencje nabywcze konsumentów i postawa smart shopping}

Wybór miejsca dokonywania zakupów przez konsumentów ma - poza aspektem finansowym - również podłoże pozadochodowe. Przede wszystkim wzrasta poziom świadomości konsumenckiej Polaków. Dzięki powszechnemu dostępowi do internetu mają oni szerokie możliwości zdobywania przydatnych informacji, m.in. odnośnie do właściwości produktów konsumpcyjnych, atrakcyjnych ofert handlowych i promocji. W szczególności wyraźnie wzrasta wiedza konsumentów na temat nabywanych produktów, w tym w zakresie ich jakości, zawartości, wartości odżywczych, walorów ekologicznych czy aspektów zdrowotnych (Koniorczyk, 2014, s. 16).

W drugiej dekadzie XXI wieku coraz większa część klientów kieruje się takimi przesłankami, jak: wygoda dokonywania zakupów, oszczędność czasu, ograniczenie kosztów dojazdu czy planowanie koszyka zakupów (Gardocka-Jałowiec, 
2015, s. 314). Wśród polskich konsumentów zaczyna rozpowszechniać się formuła zachowań nabywczych określana jako smart shopping. Należy to rozumieć jako skłonność konsumentów do zaangażowania czasu i wysiłku w poszukiwanie atrakcyjnych ofert produktowych, korzystanie z promocji cenowych czy porównywanie cen w różnych sklepach. Cechą charakterystyczną polskich konsumentów, mieszczącą się $\mathrm{w}$ formule smart shopping, jest odmienna w stosunku do większości krajów europejskich forma dokonywania zakupów. Polega to na częstym odwiedzaniu sklepów położonych w pobliżu miejsca zamieszkania lub aktualnego przebywania konsumentów. Według badań CBOS, najliczniejsza grupa Polaków robi regularnie (codziennie lub kilka razy w tygodniu) zakupy produktów na bieżące potrzeby, na ogół nie nabywając ich na zapas (Komunikat..., 2013, s. 2). Taka postawa konsumencka sprzyja przede wszystkim sklepom małoformatowym, dyskontom i supermarketom typy proximity położonym na osiedlach mieszkaniowych.

Preferencje nabywcze konsumentów wynikają również $\mathrm{z}$ dominujących i rozwijających się trendów konsumenckich. Do najważniejszych tendencji w zakresie zachowań polskich nabywców, mających wpływ na rozwój i strukturę polskiego rynku spożywczego, należy zaliczyć szybki tryb życia, dbanie o zdrowe odżywianie oraz dążenie do wygody (Sobczyk, 2018, s. 178). Ze względu na liczne obowiązki i różnorodne formy rozrywki, rosnąca część mieszkańców Polski dąży do minimalizowania czasu przeznaczonego na bieżące zakupy. $Z$ tego względu preferowane są sklepy spełniające oczekiwania nabywców pod względem takich kluczowych czynników, jak: bliskość położenia, asortyment dostosowany do potrzeb, przystępna cena, wygoda, komfort i pozytywne doświadczenia zakupowe (Bliskość sklepu..., 2015).

\section{Struktura handlu detalicznego w Polsce}

Uwzględnienie najważniejszych zjawisk w handlu detalicznym branży FMCG pozwala przedstawić tezę, że rynek podlega wyraźnym przeobrażeniom o charakterze strukturalnym. Podłożem tych przemian jest długookresowa ekspansja sieci nowoczesnego handlu wielkopowierzchniowego, która odbywa się kosztem tradycyjnych placówek handlowych posiadających nieporównywalnie mniejszy potencjał ekonomiczny (Kondej, 2006, s. 224). Dotyczy to głównie przewagi konkurencyjnej sieci zagranicznych w takich dziedzinach, jak: poziom cen, asortyment produktowy, know-how, wizualizacja i aranżacja powierzchni, standardy obsługi klientów, promocje sprzedaży, reklama i in. W efekcie tych przeobrażeń, następowało sukcesywne zwiększanie udziałów rynkowych sieci tzw. handlu nowoczesnego, w zdecydowanej większości zarządzanych przez międzynarodowe korporacje handlowe (Wykres 4). 

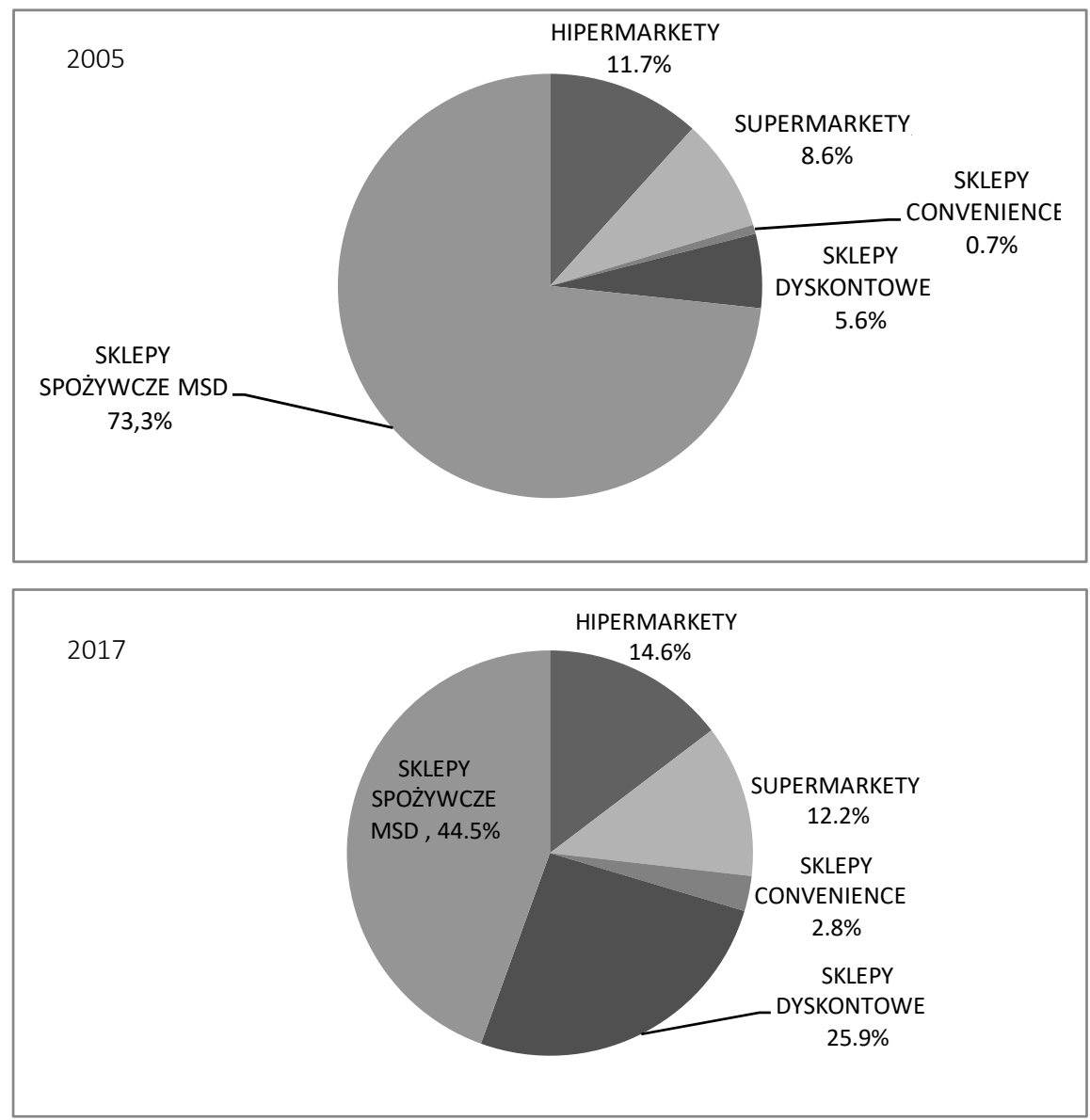

Wykres 4. Struktura wartościowa formatów rynku spożywczego w latach 2005 i 2017

Źródło: Opracowanie własne na podstawie: Baza sieci detalicznych, 2018

Na strukturalny charakter zmian na rynku wskazuje zjawisko spadku liczby sklepów przy jednoczesnym zwiększaniu się wartości sprzedaży detalicznej i łącznej powierzchni sprzedażowej (Wykres 5). Poprawiają się również parametry jakościowe sektora, co potwierdza m.in. wzrost średniej powierzchni sprzedażowej sklepu spożywczego i postęp w zakresie efektywności mierzonej wartością sprzedaży detalicznej w przeliczeniu na sklep i na metr kwadratowy powierzchni sprzedażowej (Strategie konkurencji..., 2005, s. 13).

Przekształcenia strukturalne rynku można traktować jako przechodzenie sektora handlu detalicznego FMCG z fazy wzrostu ilościowego w fazę rozwoju jakościowego. Zjawisko takie jest charakterystyczne dla dojrzewającego rynku, na którym intensywna konkurencja sprzyja zarówno koncentracji rynku, jak i poprawie parametrów związanych z jakością i efektywnością prowadzonej działalności. 


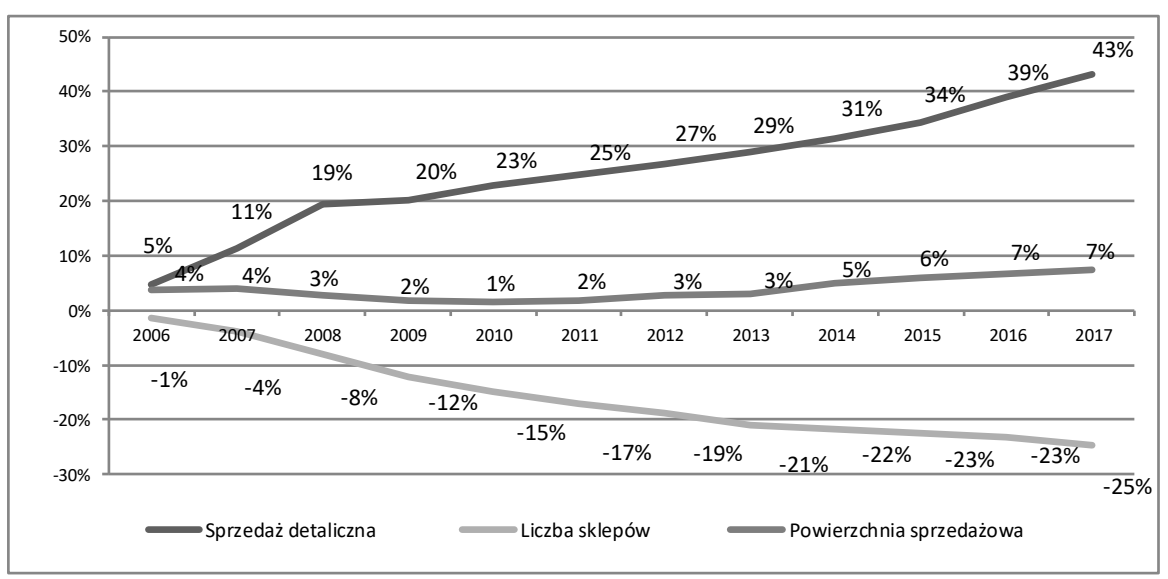

Wykres 5. Dynamika sektora handlu ogólnospożywczego w latach 2006-2017

Źródło: Opracowanie własne na podstawie: Baza sieci detalicznych, 2018.

\section{Cykl życia formatów handlowych}

Struktura sektora handlu spożywczego na rynku krajowym w znacznym stopniu uwarunkowana jest zmianami w zakresie poszczególnych formatów (Musso, 2014, s. 108). Spadkowy trend w zakresie liczby sklepów spożywczych jest zasadniczo efektem regresu $\mathrm{w}$ formacie placówek małoformatowych (do $300 \mathrm{~m}^{2}$ powierzchni sprzedażowej), który obserwowany jest od 2006 roku. W okresie 2006-2017 pozostałe formaty charakteryzował wzrost liczbowy, jednakże ze zróżnicowaną dynamiką w poszczególnych latach.

Hipermarkety w Polsce były najintensywniej rozwijającym się formatem w pierwszych latach XXI wieku (Kosińska-Gębska, Tul-Krzyszczuk \& Gębski 2011, s. 53). Sklepy wielkopowierzchniowe przez wiele lat cieszyły się dużą popularnością wśród polskich konsumentów, stanowiąc dla nich jeden z przejawów zachodniego stylu życia. W placówkach tych pod jednym dachem stworzono nabywcom możliwość zakupu szerokiego asortymentu wyrobów FMCG i przemysłowych w atrakcyjnych cenach. Spadek dynamiki rozwoju tych placówek od 2008 roku wynika z rosnącego preferowania przez polskich konsumentów sklepów mniejszych formatów położonych bliżej ich miejsca zamieszkania. Główni operatorzy hipermarketów podejmują działania dostosowawcze w zakresie modernizacji i zmniejszania powierzchni sprzedażowych oraz rozszerzania zakresu usług okołosprzedażowych. 


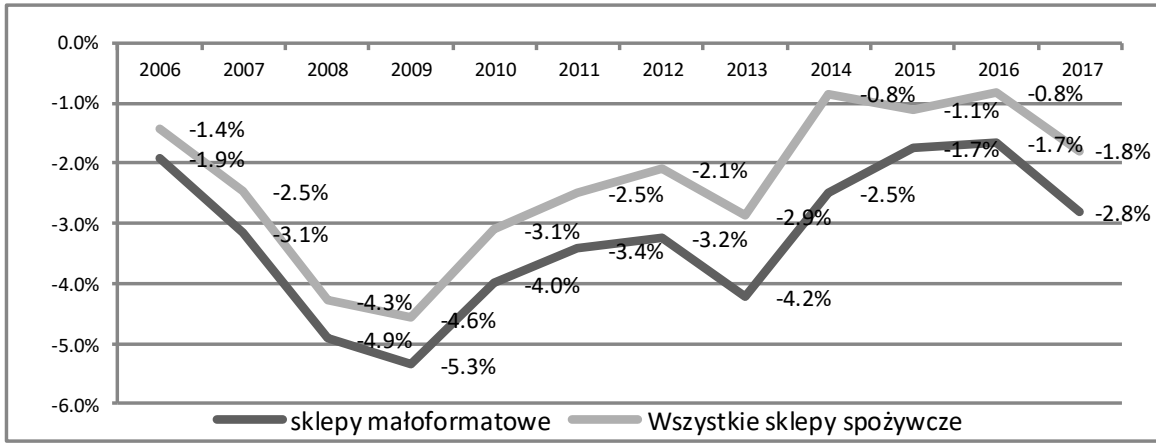

Wykres 6. Tempo spadku liczby małoformatowych sklepów spożywczych ${ }^{7}$ w latach 2006-2017

Źródło: Opracowanie własne na podstawie: Baza sieci detalicznych, 2018

Sieci dyskontowe do 2013 roku notowały najwyższą ze wszystkich formatów, dwucyfrową dynamikę wzrostu pod względem wartościowym. Sklepy tego typu oferują akceptowalne jakościowo produkty w atrakcyjnych cenach, a dzięki intensywnej ekspansji terytorialnej stały się dostępne dla większościowej populacji polskich konsumentów. Placówki dyskontowe w Polsce upodabniają się do supermarketów pod względem wystroju, wyposażenia technicznego i oferty produktowej, co umożliwia dotarcie do klientów reprezentujących różne grupy dochodowe. Od 2014 roku dynamika wzrostu tych sieci słabnie, co jest wynikiem rosnącej konkurencji ze strony supermarketów, sieci małych sklepów spożywczych i sklepów convenience. (Grocery retail..., 2016).

Supermarkety oferują klientom szeroki asortyment z dużym udziałem produktów kategorii świeżych. Sieci tego formatu zwiększają konkurencyjność w stosunku do dyskontów poprzez obniżanie cen, wprowadzanie marek własnych i oferowanie dodatkowych usług, co wpływa na zwiększenie poziomu zadowolenia klientów. Format ten jest jednak relatywnie rozdrobniony, co implikuje wysoką podatność na procesy konsolidacyjne, w tym fuzje i akwizycje mniejszych sieci przez największych operatorów. Największą dynamikę rozwoju wykazują supermarkety proximity, charakteryzujące się mniejszą powierzchnią sprzedażową (od $300 \mathrm{~m}^{2}$ ), położone w miejscach dogodnych dla klientów i oferujące asortyment węższy niż w większych supermarketach.

Sklepy convenience stanowią format znajdujący się w Polsce w fazie dynamicznego wzrostu. Wskazuje na to najwyższy spośród wszystkich formatów wskaźnik wzrostu wartości sprzedaży oraz stałe zwiększanie liczby placówek handlowych. Te małe sklepy oferują szybkie i wygodne zakupy produktów pierwszej potrzeby, nabywanych przez konsumentów najczęściej w formie impulsowej. Coraz częściej stanowią one miejsce dokonywania szerszych pod względem asortymentowym

\footnotetext{
${ }^{7}$ Sklepy małoformatowe w niniejszym oznaczają małe, średnie i duże sklepy spożywcze (do $300 \mathrm{~m}^{2}$ powierzchni sprzedażowej). W pracy stosowany jest również wymiennie skrót MSD, oznaczający małe, średnie i duże sklepy spożywcze.
} 
zakupów uzupełniających. Przez wiele lat barierą rozwojową sieci tego formatu były ceny wyraźnie przekraczające średni poziom krajowy. Obecnie czynnik ten odgrywa malejącą rolę dla klientów odwiedzających te placówki handlowe. Wynika to ze wzrostu dochodów rozporządzalnych konsumentów przy jednoczesnym wzroście konkurencyjności cenowej sklepów należących do tego formatu.

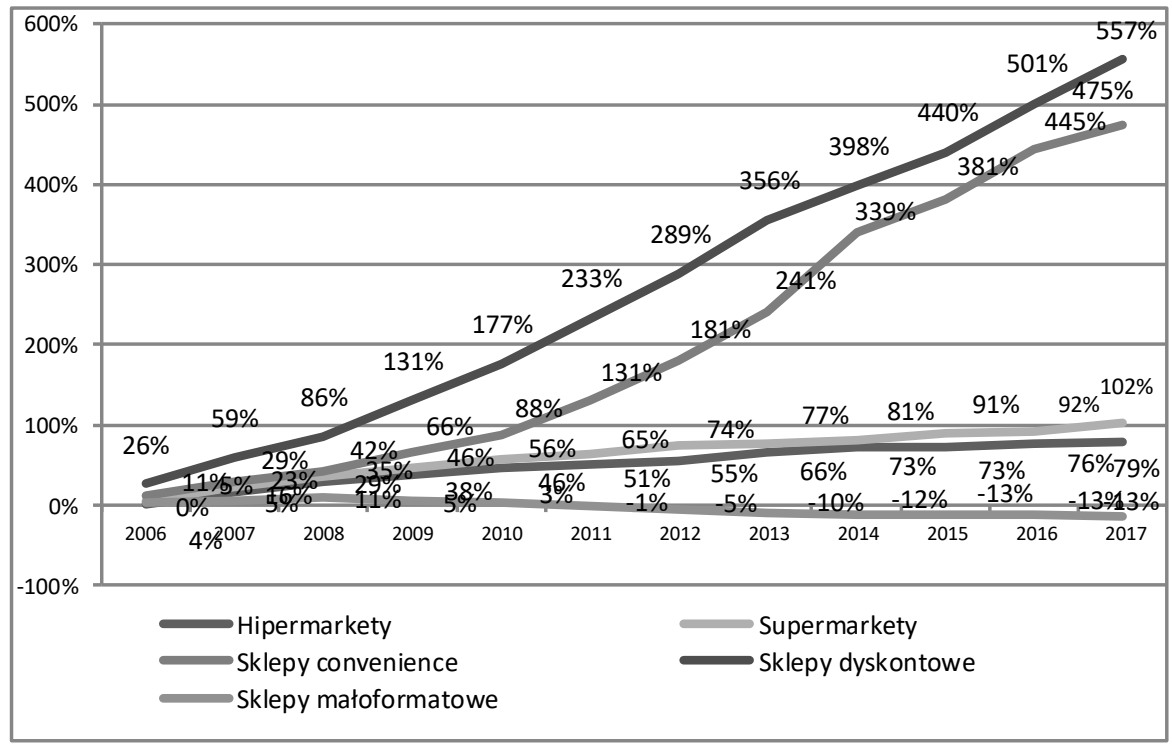

Wykres 7. Dynamika wzrostu wartościowego formatów handlowych w okresie 2006-2017

Źródło: Opracowanie własne na podstawie: Baza sieci detalicznych, 2018

\section{Etyczne i społeczne skutki ograniczenia handlu w niedziele}

U podstaw wprowadzenia zakazu handlu w niedziele leżało wiele pozytywnych założeń, zarówno pod względem społecznym, jak i ekonomicznym. Chodziło głównie o zabezpieczenie interesu pracowników, by mieli dni wolne na odpoczynek i spędzenie czasu z rodziną. W szerszym kontekście społecznym ustawa miała ograniczyć zjawisko konsumpcjonizmu polegające na nabywaniu produktów jako głównej formy zaspokajania potrzeb ludności (Analiza obywatelskiego projektu..., 2016). W zamian za to konsumenci mieli przenieść swoje zainteresowania na spędzanie czasu w gronie rodzinnym, w tym na korzystanie $\mathrm{z}$ usług gastronomicznych, rozrywkowych, z przestrzeni miejskich czy z oferty kulturalnej. Pod względem ekonomicznym intencją ustawodawcy była poprawa kondycji niewielkich sklepów o rodzimym kapitale i ograniczenie roli wielkich sieci handlowych, należących głównie do zagranicznych korporacji. 
Po 12 miesiącach funkcjonowania ustawy można mówić o jej efektach daleko odbiegających od przyjętych założeń. W ograniczonym zakresie uzyskany został efekt ekonomiczny. Okazało się, że w 2018 roku obniżył się poziom konkurencyjności handlu małoformatowego, a wysoką dynamikę wzrostu wykazały sieci dyskontowe, placówki na stacjach paliwowych i sklepy convenience. Sieci dyskontowe zastosowały agresywne promocje cenowe w dniach poprzedzających niedziele wolne od handlu, co w znacznym stopniu przyczyniło się do zmiany zwyczajów nabywczych polskich konsumentów. W większym niż wcześniej zakresie dokonują oni planowanych zakupów na kilka dni w sklepach dyskontowych, które dzięki temu rozszerzyły bazę klientów. Nastąpił dynamiczny wzrost sprzedaży na stacjach paliwowych, należących w większości do krajowych i międzynarodowych korporacji. Beneficjentem tej ustawy jest również sieć Żabka, której sklepy mają formalny status placówek pocztowych. Wdrożenie ustawy nie powstrzymało spadku liczby małych sklepów spożywczych, a ich szacowane obroty spadły w 2018 roku o ok. 6\% (Gospodarcze skutki..., 2019). Na zakazie skorzystały jedynie sklepy położone w dogodnych lokalizacjach, prowadzone bezpośrednio przez ich właścicieli. $\mathrm{W}$ efekcie nastąpiło przeniesienie strumienia handlu do dużych sieci handlowych, które mają większe budżety promocyjne i silniejsze zdolności pozyskiwania klientów niż placówki małoformatowe, w szczególności małe sklepy spożywcze.

W efekcie wprowadzenia zakazu handlu w niedziele nastąpiła również zmiana struktury zatrudnienia w handlu. W ciągu trzech pierwszych kwartałów 2018 roku ograniczona została liczba pracowników najemnych, a zwiększyła się liczba pomagających bezpłatnie członków rodziny. Pracownicy uzyskali wprawdzie wolne niedziele, ale znacząco zwiększyło się obciążenie ich pracą w soboty (wzmożony ruch klientów i wydłużone godziny otwarcia) i poniedziałki (wcześniejsze zatowarowanie sklepów) (Gospodarcze skutki..., 2019).

Można $\mathrm{z}$ kolei mówić o zmianie formy spędzania wolnego czasu przez konsumentów. Z badania przeprowadzonego przez firmę Selectivv w pierwszym kwartale 2019 roku wynika, że w niedziele wolne od handlu na rekreację na świeżym powietrzu (w parkach, na placach zabaw i terenach spacerowych) decydowało się znacznie więcej osób niż w niedziele handlowe. Podobne zjawisko występuje w odniesieniu do odwiedzania kin i korzystania z usług gastronomicznych (Dyskonty..., 2019). Ustawa nie przyniosła natomiast zauważalnego wzrostu zainteresowania usługami z obszaru kultury, co może być efektem ograniczonej promocji lub braku odpowiedniej oferty w tym zakresie.

Reasumując, w ramach zakładanych celów gospodarczych wdrożona ustawa umożliwiła ich realizację w minimalnym zakresie. Okazało się, że mnogość wyjątków w zakresie zwolnień z zakazu, a także bardzo duży potencjał rynkowy międzynarodowych korporacji handlowych spowodowały, iż wprowadzone przepisy przyczyniły się do niekorzystnego z punktu widzenia konsumentów zjawiska wzrostu udziałów rynkowych największych operatorów. 


\section{Podsumowanie}

Polski rynek handlu detalicznego branży FMCG przeszedł w ciągu ostatnich 30 lat różne fazy rozwoju. Składa się na to odmienna dynamika przemian w poszczególnych formatach handlowych, które wykazywały rozwój zbliżony do zasadniczych faz cyklu życia na rynku. W sensie ogólnym w okresie do 2005 roku obserwowano rozwój ilościowy wszystkich formatów. Od 2006 roku zaczęła się coraz wyraźniej zarysowywać tendencja do rozwoju sklepów średnioformatowych położonych w pobliżu miejsca zamieszkania potencjalnych klientów. Okazało się, że tego typu placówki w sposób optymalny spełniają oczekiwania klientów w odniesieniu do rodzaju asortymentu, poziomu cenowego, wygody, szybkości zakupu i doświadczeń nabywczych. Chodzi przede wszystkim o skłonność nabywców do dokonywania częstych zakupów w placówkach położonych blisko ich miejsca zamieszkania.

Powszechna wśród polskich konsumentów postawa smart shopping sprzyja utrzymywaniu się zdywersyfikowanej struktury rynku, co jest zjawiskiem unikatowym w skali europejskiej. W drugiej dekadzie XXI wieku można mówić o początkowym stadium nasycenia rynku, czego przejawem jest nasilająca się konkurencja w zakresie cen, jak również czynników jakościowych. Aktywność operatorów na polu wdrażania nowych rozwiązań okołosprzedażowych wywołuje zjawisko konwergencji, polegające na zacieraniu się wyraźnych wcześniej różnic między formatami. Stopniowo rozwija się również proces koncentracji rynku, będący efektem zarówno działań konsolidacyjnych (przejęć i akwizycji), jak i stałego zmniejszania się liczby małych i średnich sklepów spożywczych. Wbrew intencjom ustawodawcy, ustawa o zakazie handlu w niedziele nie ograniczyła tego negatywnego trendu i nie przyczyniła się do wzmocnienia konkurencyjności rodzimego handlu wobec międzynarodowych operatorów posiadających dominującą pozycję na polskim rynku.

\section{Bibliografia}

Alexander, N., \& Doherty, A. M. (2009). International retailing. Oxford University Press.

Analiza obywatelskiego projektu ustawy o ograniczeniu handlu $w$ niedziele. (2016). https://ordoiuris.pl/wolnosc-gospodarcza/analiza-obywatelskiego-pro jektu-ustawy-o-ograniczeniu-handlu-w-niedziele

Analiza PIH: Jak podatek od dyskontów i hipermarketów może wzmocnić właścicieli polskich sklepów? (2016). http://www.pih.org.pl/images/analiza_pihpolski_rynek_handlu_pih_5.01.16.pdf

Bank Danych Lokalnych. (2019). GUS. https://bdl.stat.gov.pl/BDL/start

Baza Sieci Detalicznych. (2019). Kondej Marketing. www.kondejmarketing.com 
Bliskość sklepu wyprzedziła niskie ceny $w$ rankingu czynników decydujących o miejscu zakupów. (2015). http://www.dlahandlu.pl/detal-hurt/wiadomo sci/raport-bliskosc-sklepu-wyprzedzila-niskie-ceny-w-rankingu-czynnikow -decydujacych-o-miejscu-zakupow,46584.html

Dąbrowska, A., \& Słaby, T. (2011). Sytuacja małych sklepów w Polsce. Małe sklepy osiedlowe. Raport z badań [raport wykonany na zlecenie Makro Cash and Carry Polska SA]. Warszawa.

Dyskonty, drogerie i stacje benzynowe największymi beneficjentami zakazu handlu $w$ niedziele. (2019). https://www.wiadomoscihandlowe.pl/artykuly/dyskon ty-drogerie-i-stacje-benzynowe-najwiekszymi-,53494

Gardocka-Jałowiec, A. (2015). Zmiany konsumpcji a kreowanie innowacji. Białystok: Wydawnictwo Uniwersytetu w Białymstoku.

Gospodarcze skutki ograniczenia handlu w niedziele - realizacja czarnego scenariusza. (2019). Związek Przedsiębiorców i Pracodawców. http://zpp.net.pl/ wp-content/uploads/2019/03/Gospodarcze-skutki-ograniczenia-handlu-wniedziele.pdf

Grocery retail in Poland 2010-2020 - detailed analysis of convenience and proximity supermarkets segments. (2016). Roland Berger. https://www.roland berger.com/it/Publications/Polish-grocery-retail-market-2010-2020.html

Handel w Polsce szybko się przeobraża. (2016). https://www.wiadomoscihandlo we.pl/artykuly/handel-w-polsce-szybko-sie-przeobraza,6800/1

Kaczmarek, T. (2010). Struktura przestrzenna handlu detalicznego. Poznań: Bogucki Wydawnictwo Naukowe.

Komunikat z badań BS 94/2013. (2013). CBOS. https://www.cbos.pl/SPISKOM. POL/2013/K_094_13.PDF

Kondej, A. (2006). Przeobrażenia w strukturze polskiego handlu detalicznego na przykładzie Łomży. W: A. Chmielak, \& B. Plawgo (Eds.), Przedsiębiorczość jako czynnik rozwoju regionu. Łomża: Wydawnictwo Państwowej Wyższej Szkoły Informatyki i Przedsiębiorczości w Łomży.

Kondej, A. (2017). Wplyw zróżnicowania dochodów konsumentów na rozwój przedsiębiorstw handlowych branzy FMCG (Fast Moving Consumer Goods) w Polsce [praca doktorska]. Białystok: Uniwersytet w Białymstoku.

Koniorczyk, G. (2014). Smart shopping a zachowania zakupowe polskich konsumentów. Handel Wewnętrzny, 3(350), 15-24.

Kosińska-Gębska, M., Tul-Krzyszczuk, A., \& Gębski, J. (2011). Handel detaliczny żywnościa $w$ Polsce. Warszawa: Wydawnictwo SGGW.

Kowalska, K. (2012). Rozwój polskich sieci detalicznych jako sposób ograniczania sity rynkowej międzynarodowych korporacji handlowych. Warszawa: Difin. 
Kucharska, B., \& Twardzik, M. (2007). Koncentracja i integracja $w$ handlu. Aspekt teoretyczny. Dąbrowa Górnicza: Wyższa Szkoła Biznesu w Dąbrowie Górniczej.

Musso, F., \& Druica, E. (2014). Handbook on research on retailer-consumer relationship development. Londyn: IGI Global.

Sieci detaliczne na rynku FMCG w Polsce - raport GFK. (2016). https:// www.wiadomoscihandlowe.pl/artykuly/sieci-detaliczne-na-rynku-fmcg-wpolsce-raport-gfk, 7576

Sławińska, M. (Ed.). (2015). Strategie konkurencji $w$ handlu detalicznym $w$ warunkach globalizacji rynku. Poznań: Wydawnictwo Akademii Ekonomicznej w Poznaniu.

Sobczyk, G. (2018). Zachowania konsumentów wobec nowych trendów konsumpcji - wyniki badań. Annales Universitatis Mariae Curie-Skłodowska. Oeconomica, 52(1), 171-180.

Wilk, W. (2013). Miasta zbyt małe na handel z dyskontem. Acta Universitatis Lodziensis. Folia Geographica Socio-Oeconomica, 15, 21-37. 